\title{
A CSATORNA-SZIGETEK TÖRTÉNETILEG VÁLTOZÓ GAZDASÁGI-TÁRSADALMI KIHÍVÁSAI
}

\author{
(Socio-economic Challenges of the Channel Islands in a \\ Historical Perspective)
}

ZÁDORI IVÁN

\begin{abstract}
Kulcsszavak:
Csatorna-szigetek Guernsey Jersey autonómia alkalmazkodási kényszer diverzifikáció adaptáció fenntarthatóság

Jelen tanulmányban a Csatorna-szigetek, Guernsey és Jersey gazdasági és társadalmi kérdései kerülnek bemutatásra a kezdetektöl napjainkig. A Csatorna-szigetek története a sikeres adaptáció története. $A$ rendszeresen jelentkezö diverzifikációs kényszer újabb és újabb gazdasági tevékenységek felé történö elmozdulást generál, melyekkel a szigetek kedvezö helyzete folyamatosan fenntartható. A vizsgált szigetek sikeressége és versenyképessége ugyanakkor alapvetōen az Egyesült Királyság és a szigetek 1204 óta fennálló sajátos viszonyrendszerére vezethetó vissza, ahol mindkét fél profitál a különleges státuszszabályok által fenntartott szituációból.
\end{abstract}

\section{Bevezetés}

$\mathrm{Az}$ uniós dokumentumokban az európai szigetek és szigetrégiók jelentős része alapvetően elmaradott, hátrányos, strukturális problémákkal küzdó területeknek tekintett, ahol leginkább a szigetek gazdaságának sérülékenysége kerül kiemelésre, különösen azokban az esetekben, ahol a gazdasági specializáció fokozottabban figyelhető meg, kiemelve az infrastrukturális problémákat, a szociális és közszolgáltatások megfelelő biztosításának gyengeségét vagy hiányát, illetve a méretgazdaságosságból fakadó problémákat is. A 286 sziget jellegü területre ${ }^{1}$ vonatkozó vizsgálat alapján néhány kivételtỏl eltekintve a szigetek gazdasági és szociális helyzete rosszabb azoknak az országoknak az átlagához képest, amelyekhez tartoznak (Analysis... 2003). A vizsgált szigeteken az egy före jutó GDP általában alatta marad az országos átlagoknak, ugyanakkor nem minden terület helyzete tekinthetö kedvezőtlennek, 2002-ben a 2004-es bővítés elötti 21 európai sziget-régió GDP-je 3 esetben haladta meg az EU 15-ök átlag GDP-jét, méghozzá a Baleár-szigetek, Aland és Shetland esetében (Off The Coast... 2002). A három jól teljesitö szigetrégió közül a Baleár-szigetek esetén a turizmusnak van kitüntetett szerepe, Shetland esetében az olaj, a halászati területek és a „web-gazdaság” jelentős, Aland esetében pedig az I. világháborút lezáró békeszerzỏdések következtében kialakult sajátos gazdasági és politikai autonómiának köszönhető az önrendelkezés magasabb foka, melynek következtében a Finnországhoz tartozó, de meghatározó svéd lakossággal rendelkező szigetcsoport gazdasága jobban teljesit, elsősorban az önálló adórend- 
szerének, valamint a hajóregisztrációs lehetóségeknek köszönhetően. Ugyanakkor az Európai Unió 21 sziget-régióján kívül léteznek olyan szigetek is, amelyek ugyan EUtagország „felségterületei”, de nem EU-tagok. Ezen szigetek egy része, a Feröerszigetek, a Csatorna-szigetek és a Man-sziget földrajzilag Európához tartozik, másik, lényegesen nagyobb része pedig elsősorban Közép- és Észak-Amerikában, valamint a Csendes-Óceánon található, az európai anyaországokkal való kapcsolataikat pedig az esetek többségében sajátos föderalisztikus viszonyrendszer és az autonómia különböző fokai jellemzik. Jelen tanulmányban az említett speciális helyzetü területek közül a Csatorna-szigetek, Guernsey és Jersey (1. ábra) gazdasági és társadalmi kérdései kerülnek bemutatásra. A Csatorna-szigetek története a sikeres adaptáció története, a 15-16. századtól kezdődik meg a szigetek bekapcsolódása egyre intenzivebben a regionális és a nemzetközi kereskedelembe és a különféle gazdasági tevékenységekbe, a szigetlakók pedig sikeresen használják ki az éppen aktuális világgazdasági trendeket, fenntartva a speciális alkotmányos kapcsolatot, amely 1204-től biztosítja a szigeteknek az Egyesült Királyságon belüli sajátos ,in and out” státuszát, elónyeivel és hátrányaival együtt.

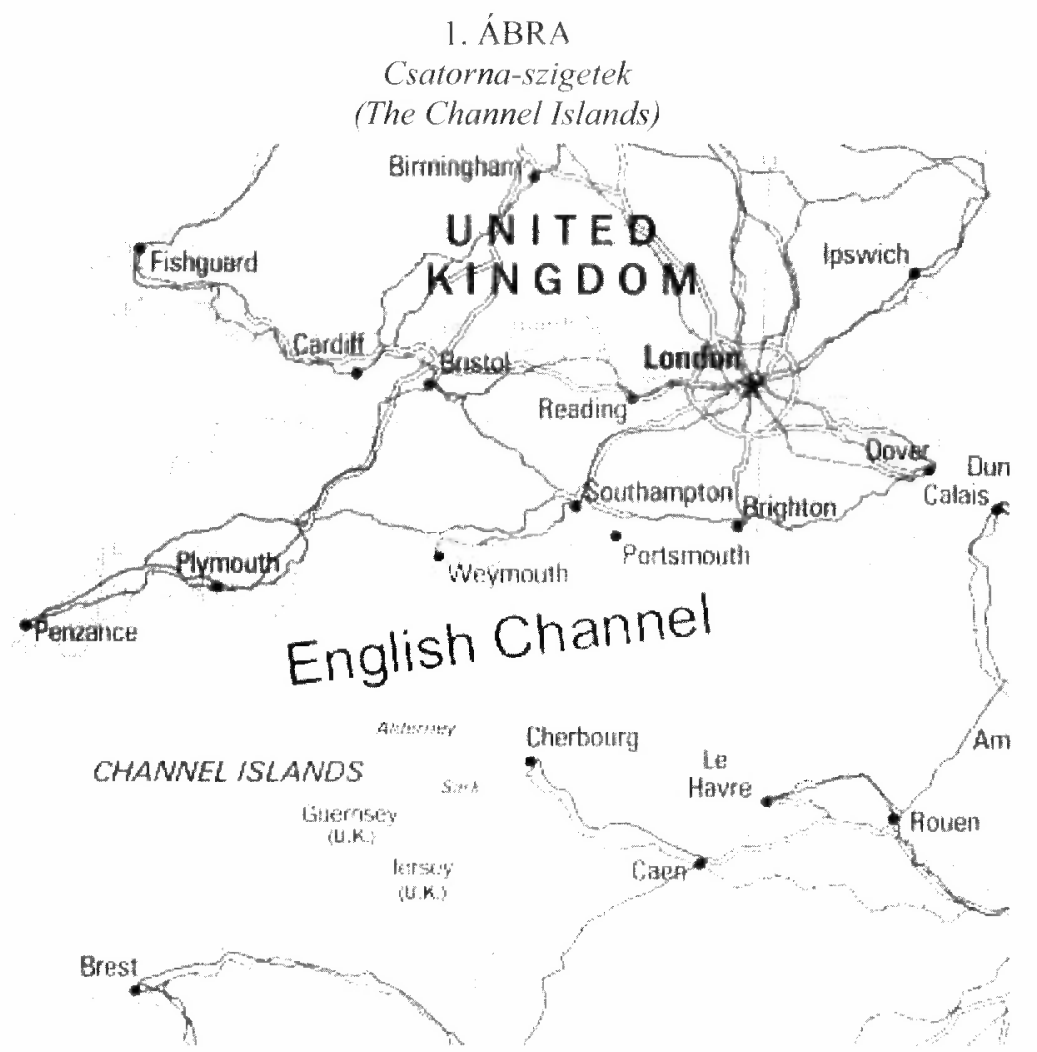

Forrás: http://upload.wikimedia.org/wikipedia/commons/b/b8/English_Channel.jpg 
Zádori Iván : A Csatorna-szigetek történetileg változó gazdasági-társadalmi kihívásai.

Tér és Társadalom 22. évf. 2008/2. 203-228. p.

TÉT XXII. évf. 2008 - 2

Kitekintö

205

A Csatorna-szigetek Normandia partjai előtt helyezkednek el. Területükön két kormányzóság (Bailiwick) található, a 91 ezer fỏ lakossággal rendelkező és 116 négyzetkilométer területü Jersey és a hozzá kapcsolódó kisebb szigetek (Dirouilles, Barnouics, Minquires és Ecrehous), illetve a 65 ezer fös, 65 négyzetkilométer területủ Guernsey Kormányzóság a hozzá tartozó Alderney, Sark, Herm, Jethou szigetével és néhány kisebb szigettel (Lihou, Burhou és Brecqhou) együtt (CIA Factbook 2007). A szigetek évszázadok óta müködő autonómiája és függetlensége sajátos igazgatási formák kialakulását eredményezte, melyben az ősi hagyományok keverednek bizonyos angol és francia jellegzetességekkel. A kormányzóságok (the States) feje II. Erzsébet királynő. A „States” vezetője a kormányzó (Bailiff, a király/királynő jelöli ki), és a helyettese (Deputy Bailiff), továbbá a koronát képviselö helyettes kormányzó (Lieutenant Governor, szintén a király/királynö jelöli ki). A jogrendszer az angol jogra épül különféle speciális helyi rendeletekkel, törvényekkel, amelyek felügyeletét a Royal Court látja el. Írott alkotmány nincs, szokásjog, közösségi joggyakorlat az, ami az egyes folyamatokat, jogokat és kötelezettségeket szabályozza. A törvényhozó testület az egykamarás parlament, nincsenek politikai pártok, a delegált képviselők függetlenek. A parlament tagjai a korona képviselöi is, akiknek megfigyelő, illetve bizonyos szituációkban tanácsadó szerepük van. A Csatorna-szigetek lakói nem szavazhatnak az Egyesült Királyság parlamenti választásain, az Egyesült Királyság kormánya csupán a védelemért és külkapcsolatokért felelós, minden egyéb ügy, beleértve az adórendszert is a kormányzóságok hatáskörébe tartozik. A szigetek kapcsolata az Egyesült Királysághoz kizárólag az angol koronán keresztül történik, mert a mindenkori angol uralkodó egyben Normandia hercegi címét is viseli. A szigetek nem tagjai az Európai Uniónak és nem is társult tagjai. A szigeteknek csupán korlátozott, speciális kapcsolata van az EU-val, amit az Egyesült Királyság csatlakozását deklaráló 1972-es törvény szabá${ }_{1 y o z}{ }^{2}$. Ezen rendelkezések szerint a szigetek részei az EU vámterületének. A közösségi vámtarifák, adóterhek és egyéb mezőgazdasági importkvóták szabályozzák a kereskedelmet abban az esetben, ha EU-n kívüli országról van szó, és a tagországokkal a szabad kereskedelem, áruk és szolgáltatások szabad áramlása valósul meg. Más szabályozás nem vonatkozik kötelező jelleggel a szigetekre.

A tanulmányban bemutatásra kerüló gazdasági, társadalmi folyamatok logikája 1204 óta nem változik számottevően: a sajátos autonómia és politikai státusz fenntartása folyamatosan kiemelt jelentőséggel bír, mint ahogy az új kihívásokkal kapcsolatban időröl időre jelentkező alkalmazkodási kényszer sem változik, és továbbra is az új diverzifikációs lehetöségek irányába történő elmozdulás, a lehetöség szerint sikeres adaptáció és a versenyképesség megőrzése a kulcsa a vizsgált szigetgazdaságok hosszú távú fenntarthatóságának. 


\section{A kezdetektöl a 16. századig}

Az utolsó jégkorszak végéig a szigetek egybefüggő szárazföldet alkottak a normandiai partvidékkel, csak a tengerszint megemelkedésével szakadtak el a kontinenstöl. A leszakadás azonban csak lassan ment végbe, és a későbbi korokban is viszonylag könnyen elérhető volt a szárazföldról. Az emberi jelenlétnek megközelítỏen 5000 éve vannak nyomai a szigeteken. Időszámításunk szerint 56-ban kerültek a Csatorna-szigetek római fennhatóság alá, ebben a periódusban elsősorban kereskedelmi központként, kikötőhelyként funkcionáltak. Guernsey esetében kedvezőbbek voltak a kikötési feltételek, Jersey esetében ugyanakkor a mezőgazdasági tevékenységek jutottak lényegesebb szerephez.

933-ban a szigetek viking fennhatóság alá kerültek, amikor Rollo fia, Hosszúkardú Vilmos a Normandiai hercegséghez csatolta öket. A következő jelentős dátum 1066, amikor Hitvalló Edward halála után kialkult trónviszályt követően Hódító Vilmos, Normandia hercege elfoglalja Angliát, és királlyá koronázzák. Ettől az időponttól kezdve az angol koronához tartoznak a Csatorna-szigetek, de már ekkor saját önkormányzattal rendelkeztek (Johnston 1994).

933-tól 1204-ig a szigetek Normandiához tartoztak, elsősorban normann, világi és egyházi földbirtokosok uralma alatt, akik folyamatosan különféle kedvezményekkel próbáltak telepeseket a szigetekre csábítani, illetve próbálták megtartani a népességet, ami nem volt „nehéz”, mert a klasszikus jobbágyság a szigeteken, ellentétben a szomszédos francia területekkel, soha nem jött létre (Coysh 1977). 1204 lényeges fordulópont volt a Csatorna-szigetek történetében, mert ebben az évben János angol király elvesztette Normandiát, II. Fülöp francia király kiszorította az angolokat Franciaország területérỏl. A szigetlakóknak el kellett dönteniük, hogy továbbra is hüségesek lesznek az angol koronához, vagy az elfoglalt Normandiával együtt francia fennhatóság alá kerülnek. Angliát választották: ezért 1215-ben az immár Földnélküli János angol király bizonyos jogokat és privilégiumokat adományozott, amelyek továbbra is lehetővé tették az Angliától független önkormányzatiságot, (napjainkig) megőrizve a normann igazgatási hagyományokat. Az 1204-es változások nem szüntették meg a korábbi évszázados kereskedelmi, kulturális, családi, egyházi és egyéb birtokkapcsolatokat azonnal. Az egyik legerősebb kapcsolat az egyházi kapcsolat: 1204 elött 14 normandiai egyház rendelkezett fiókegyházzal (és természetesen jövedelmekkel) a szigeteken, továbbá 2 normann püspökségnek és egy normann föesperességnek voltak birtokai és egyéb kintlévőségei Guernsey-n és Jersey-n. A Csatorna-szigeteken található 25 parókia még 1414-ben is a normann apátságok és egyházak fiókegyházaiként múködött, csak 1568-ban kerültek angol felügyelet alá, amikor végül a winchesteri egyházkerülethez csatolták öket (Jamieson 1986).

A térség hadászati stratégiai jelentősége miatt az elkövetkező 200 évben a franciák nem voltak túlságosan kibékülve azzal, hogy a szigetek az angol fennhatóságot választották, ezért több alkalommal megkísérelték elfoglalni a területet, de a pusztításon kívül tartósan nem sikerült megvetni lábukat a Csatorna-szigeteken. Az „ütközőzóna” 
Zádori Iván : A Csatorna-szigetek történetileg változó gazdasági-társadalmi kihívásai.

Tér és Társadalom 22. évf. 2008/2. 203-228. p.

TÉT XXII. évf. 2008 - 2

Kitekintö

207

szerep később sem sokat változott, a százéves háború alatt 1338-ban a franciák elfoglalták a szigetek jelentős részét, de csak 1340-ig sikerült megtartaniuk. Ezek után megkezdödött a védelem tervszerü kiépitése és a szigetek különféle helyein található korábbi erődítések fejlesztése. Ettől függetlenül a támadások és csatározások tovább folytatódtak (1356, 1372 stb.) olyannyira, hogy Guernsey esetében IV. Edward angol király IV. Sixtus pápától azt kérte, hogy nyilvánítsa semlegessé a szigetet, melyet végül az 1480-as pápai bulla tett lehetôvé. Egy évre rá megalakult a Guernsey-i állam (States of Guernsey), a semlegességet pedig később kiterjesztették Jersey-re is.

A 14. századra a szigetek megművelhető területeinek jelentős részét mủvelés alá fogták, elsősorban gabonaféléket termeltek, aminek fontos szerepe volt a szigetlakók szükségleteinek kielégitésében, de kisebb mennyiségben termesztettek paszternákot, hagymaféléket, babot, borsót, lent és kendert is, valamint marhát, juhot, sertést, baromfit tenyésztettek, a tehetősebb parasztok lovakat is tartottak. Érdekes helyi gazdasági tevékenység és keresett exportcikk volt a tengeri hínár: a parton összegyüjtött, illetve a kövekről, sziklákról leszedett növények egy részét frissen, a többit feldolgozva használták fel: megszárították, elégették, és a hamu, ami sok nyomelemet, magnéziumot, káliumot tartalmaz, föleg talajjavitásra került felhasználásra. A szigeteken a halászatnak is jelentős szerepe volt, elsösorban ebben az esetben is a helyi igények kielégítése a cél, de többlet esetén exportcikként is megjelent - ebben az időszakban Guernsey-é volt a vezető szerep, de természetesen a többi szigeten is foglalkoztak sózással és szárítással. Hasonlóan a halászathoz, a hajózás tekintetében is Guernseynek volt vezetỏ szerepe (jobb kikötőhely), Jersey esetében a francia szárazföldi kapcsolatok és a mezögazdasági tevékenységek tekinthetők jelentősebbnek.

Az intenziv kereskedelmi kapcsolatoknak a gyakori háborús szituációk nem kedveztek, ugyanakkor az angol uralkodók próbáltak minél kisebb mértékben beavatkozni a szigetek életébe, folyamatos kedvező szituációt biztosítva a kereskedelemnek. $^{3}$ A szigetek kereskedelmi tevékenysége ebben az idöszakban a helyi igények kielégítésén kívül nagyrészt közvetítő kereskedelem, különösen Guernsey esetében. Angliát tekintve a szigetekhez legközelebb eső angol kikötőkkel bonyolódott a kereskedelmi kapcsolatok túlnyomó része, ahol a szigeti többlettermékek értékesítésén túl francia áruk dominálnak. A kereskedelem kisméretú hajókkal zajlott viszonylag kis tételben, komoly specializáció nélkül, kivéve néhány terméket, például a bordeauxi bort a 14. századtól kezdve.

A Csatorna-szigetek esetében sajátos kettősség, passzív és aktiv kapcsolatrendszer figyelhetö meg a tenger "használatával” kapcsolatban. A 16. századig alapvetően a passzív kapcsolat dominált, kis volumenü kereskedelmi aktivitással, de ettől kezdve, hasonlóan Angliához, a földrajzi felfedezések hatására az aktív lesz dominánsabb. A felfutás az 1870-es évekig tartott, amikor a Csatorna-szigetek, más kis angol kikötőkhöz hasonlóan, képtelenek megküzdeni az új technológiával, a gőzhajózás kihívásaival, vége a „3W" (wood, wind and water) gazdaságnak, az 1900-as évek elejére a korábban virágzó tengeri kereskedelem hamar a múlté lesz, „külső” szereplökre hagyva a szigetek kereskedelmének koordinálását. 


\section{Semlegesség és kereskedelem (1500-1689)}

A korábban már említett semleges státusz értelmében (legalábbis elméletileg) a szigetek fennhatósága alá tartozó vizeken illegális volt az ellenséghez tartozó hajókat megtámadni és elfoglalni, biztosítva a két, szinte folyamatosan háborúban álló Anglia és Franciaország közti, mindkét fél számára fontos kereskedelem lebonyolítását. Természetesen ez a semlegesség elég ingatag lábakon állt, mert időről időre elöfordultak kihágások, melyeket az érintettek teljes kártalanítására törekedve próbáltak meg elsimítani. A szigetlakók a semleges státuszon felül bizonyos árukat vámmentesen importálhattak Angliából, szerződésekben rögzitett, meghatározott kvótakeretrendszeren belül (Jamieson 1986). Ennek különösen a 17. század elejétől lett nagy jelentösége, amikor a harisnyakötö ipar felvirágzott a szigeteken, és az ehhez szükséges gyapjút Angliából szerezték be. Miután a szigeteken többszöri próbálkozásra sem sikerült angol vámhatóságot felállítani, elég nehezen lehetett kontrollálni a szigetekre behozott áruk, elsősorban a gyapjú reexportját Franciaországba. A 17. század elején sikerült a szigeteknek kiharcolniuk, hogy a Csatorna-szigeteken elöállított és megtermelt javakat vámmentesen lehessen bevinni Angliába. Ez természetesen újabb visszaélésekre és illegális kereskedelemre adott alkalmat. A kereskedelmi anomáliák ellen, bár időröl időre fókuszba kerültek, nem lépett fel senki túlzott mértékben, mert ez által több és kedvezöbb áru került a kontinensröl Angliába.

A kereskedelem továbbra is három pólus: a szigetekhez közel eső francia kikötők, a dél-, illetve délnyugat-angliai kikötők között zajlott Guernsey és Jersey közbeiktatásával, kiegyenlítve a kereskedelmi egyensúlytalanságokat, mivel a szigetek általában többet importáltak Angliából, mint amennyit exportáltak, de többet exportáltak Franciaországba, mint amennyit importáltak. E rendszer a kölcsönös megállapodások és az „elnéző" magatartás ellenére ingatag egyensúly volt, amely, ha bármilyen irányban változások vagy elmozdulások következtek be, nagyon komoly következményekkel járt az egyes felekre nézve.

A 16. század második felében a szigeteken megkezdődött a kötőipar felfutása, ami a korábbi kereskedelmi kötöttséget és függőségeket tovább erősítette: az előállított termékek jelentős része angol alapanyagból Franciaországban landolt. Az 1660-as évekre évente már 240 ezer pár harisnyát exportáltak a szigetekről (Jamieson 1986). Az egyéb importált termékekben jelentős változások nem történtek, egyedül talán a dohány behozatalát lehetne kiemelni, melynek egy része Angliából, másik része pedig az észak-amerikai angol gyarmatokról származott. Az importfüggőség különösen Guernsey esetében figyelhető meg intenzívebben, a kisebb méretü, nagyobb mértékben túlnépesedett, mezőgazdasági termelésre alkalmas megmủvelhetö területekkel korlátozottabb arányban rendelkező szigeten külső erőforrások nélkül a sziget-gazdaság már ekkor fenntarthatatlan volt. Az export a kötött termékeken és a nem túl rendszeres gabonaexporton kívül föképp vászon és textiltermékekböl, börökböl, élöállatból (birka, bárány), illetve sózott halból és disznóhúsból állt, de elöfordult a korábban már említett tengeri hínár, gránit, só és az almabor exportja is. 
Zádori Iván : A Csatorna-szigetek történetileg változó gazdasági-társadalmi kihívásai.

Tér és Társadalom 22. évf. 2008/2. 203-228. p.

Ezek a termékek azonban sem értékben, sem mennyiségben nem jelentettek komoly tételeket, a teljes export a legtöbb esetben a kötött harisnyákkal együtt is kevesebb volt, mint az import. A 17. században azonban más típusú gondok is adódtak, a fö kereskedelmi partnerek, Franciaország és Anglia protekcionista gazdaságpolitikájának köszönhetóen a korábbi kereskedelmi kapcsolatok egyre nehezebbé és körülményesebbé váltak. Az 1650-es évektől az újonnan kivetett adóknak köszönhetően a szigetek egyre inkább egymással is versenyezve próbálták a folyamatosan szüküló francia piacokon pozícióikat és profitjaikat megőrizni.

\section{A szabad kereskedelem vége, a kalózéra kezdete}

1689-ben újabb háborús konfliktus robbant ki Franciaországgal, ami a szigetek számára azzal kezdődött, hogy a francia kereskedelmi kapesolatokat egy deklaráció megtiltotta, amely, bár ideiglenes rendelkezésnek tünt, a későbbiekben tartósnak bizonyult. Ez az új helyzet a szigetek korábbi bevételi forrásait igen kedvezőtlenül érintette, egyrészt sürgősen új bevételi forrásokról kellett gondoskodni, másrészt az eddig még háború esetén is megtürt kereskedelmi kapcsolatokból származó javakat valahonnan be kellett szerezni. Az érintettek természetesen nem számolták fel a korábbi kereskedelmi kapcsolatokat egyik napról a másikra, de idővel, a háborús helyzet elhúzódásával praktikusabbnak tünt átstrukturálni ezeket a tevékenységeket a szigetlakók számára nem teljesen ismeretlen, de korábban intenzíven nem alkalmazott tevékenységek, a csempészet és a kalózkodás irányába. A „privateer” azonban nem minősíthető egyszerủen kalóznak, mert királyi felhatalmazással végzi a tevékenységét, és a megszerzett zsákmány bizonyos szabályok szerint kerül felosztásra. $1 / 5$ rész jár a királynak, a maradék zsákmány $2 / 3$-a a vállalkozás tulajdonosainak, a fennmaradó rész pedig a hajó kapitánya, tisztjei és legénysége között kerül felosztásra. Ez a tevékenység csak háború esetén, és megfelelö papírokkal, engedélyekkel (letters of marque) és meghatározott célpontok ellen volt ,legális” (ez különböztette meg a „klasszikus” kalózkodástól). Nem csupán Anglia élt ezzel a lehetőséggel, hanem a tengeri hatalmak jelentós része háborús helyzet esetén alkalmazta ezt. A kalózkodás egyrészt jó üzleti lehetőséget jelentett az érintett feleknek, másrészt alkalmas volt arra is, hogy az ellenség sorait megzavarja, kereskedelmét, utánpótlását megakadályozza, a lefoglalt javakkal pedig a korábbi kereskedelem egy része továbbra is fenntartható volt. Érdekes kérdés, hogy egy olyan területen, ahol évszázadok óta müködő, hol ellenséges, hol barátságos gazdasági, politikai, kulturális kapcsolatok jellemzik a szigetek és Franciaország viszonyrendszerét, hogyan lehet szinte egyik napról a másikra váltani? A források szerint az új típusú kereskedelem elsősorban nem vérre, hanem sokkal inkább a haszonra ment, kölcsönösen megrövidítve egymást. A kalózkodási üzlet annyira jól bevảlt, hogy ez funkcionált a szigetek, különösen Guernsey fö bevételi forrásaként, ,iparaként”. Például 1800-ban az ilyen jellegủ tevékenységből származó haszon Guernsey esetében meghaladta az 1 millió fontot, föleg francia és amerikai hajókat megrövidítve. 
Zádori Iván : A Csatorna-szigetek történetileg változó gazdasági-társadalmi kihívásai.

Tér és Társadalom 22. évf. 2008/2. 203-228. p.

A másik ,iparág”, ami hatalmas fejlődésnek indult, a csempészet volt, amit a szigetekkel foglalkozó szakirodalomban gyakran „,szabad kereskedelem” címszóval emlegetnek. A szigetek speciális helyzetükből adódóan mindig is kiválóan alkalmasak voltak különféle áruk raktározására, átrakására. Az illegális kereskedelem elsôsorban az angol gyapjú és az amerikai gyarmatokról, illetve Angliából származó dohány illegális kereskedelmét jelentette. A csempészetnek további lökést adott a szigeteken, hogy a korábbi elsődleges, komolyabb és sokkal nagyobb forgalmat lebonyolító csempészközpont, a Man-sziget ezen szerepét elvesztette azáltal, hogy a korábban különféle arisztokrata családok birtokában álló területet Duke of Atholl 1765-ben 70 ezer fontért eladta a brit kormánynak. A csempészek ezután elhagyták a szigetet áthelyezve székhelyüket Wales-be, Északnyugat-Angliába, Írországba és Délnyugat-Skóciába, de sokan a Csatorna-szigeteket választották (Johnston 1994).

A szigetek ugyanakkor elsősorban a „kínálatot” biztosították a csempészeknek, melyek más, „külföldi” csempészek által behozott áruból és a nem ellenséges területekkel lebonyolított kereskedelemböl származtak, azonban ők maguk kevésbé voltak érintettek ezekben az ügyletekben, a legtöbb csempészhajó ugyanis brit tulajdonban volt. A „hagyományoknak” és a földrajzi elhelyezkedésnek köszönhetően Jersey elsősorban a ,francia kapcsolatban”, Guernsey pedig az Angliába és Írországba irányuló csempészetben volt érdekelt. A szigetek gazdasági életében betöltött szerepüket tekintve elsősorban Guernsey és Alderney voltak a csempészet igazi központjai, Sark nem volt túlságosan érintett, föleg csak mezögazdasági aktivitás volt jellemző a szigeten, és Jersey esetében, bár volt csempészet, a sziget gazdaságát sokkal inkább meghatározta az észak-amerikai tőkehal-üzletbe való bekapcsolódás.

Az Anglia ellátásához való komoly hozzájárulás ellenére a 18. század második felétỏl az angol kormánynak nem csupán a Man-szigettel kapcsolatban voltak tervei gondoljunk az észak-amerikai gyarmatok kereskedelmének szabályozására -, a Csatorna-szigetek sem kerülhették el sorsukat, 1764-ben a kormány megrendelésére átfogó felmérés készült a témával kapcsolatban. Igazán komoly ellenlépésekre azonban még várni kellett, egészen az 1800-as évek elsö évtizedéig, amikor is a csempészet visszaszorításával kapcsolatos szabályokat hozott az angol parlament, melyeket a szigeteken is törvénybe iktattak, továbbá, több évszázados „elökészítő munka” után, vámhivatalokat állitottak fel mindkét szigeten. A csempészet, bár bonyolultabb lett, innentől kezdve „tudományos” formát öltött (ún. scientific smuggling), kevésbé volt látványos, kisebb hajókon, kisebb tételekben a 19. század közepéig folytatódott. A hanyatláshoz minden bizonnyal a brit vámpolitikai változások is hozzájárultak: az 1820-as évektől kezdve egyre fokozódó ütemben kerültek a korábbi vámtételek csökkentésre, illetve eltörlésre, a csempészet - legalábbis a korábbi évszázadokat jellemző formájában - értelmét vesztette.

A fokozódó ellenörzések, törvények és vámok hatására azonban az 1700-as évek végétöl a szigetekre újabb diverzifikációs kényszer nehezedett, ami elósegítette az újabb területek felé történő elmozdulást. Ez egyrészt a korábban is már létező, de jóval kisebb volumenủ tökehal-üzletbe történő nagyobb mértékü bekapcsolódást, másrészt a hajóépítés felfutását jelentette. Érdemes megjegyezni, hogy a speciális 
Zádori Iván : A Csatorna-szigetek történetileg változó gazdasági-társadalmi kihívásai.

Tér és Társadalom 22. évf. 2008/2. 203-228. p.

TÉT XXII. évf. 2008 — 2

Kitekintö

211

kalózkodás, valamint a csempészetből származó haszon miatt megindult a sziget lakosságának jelentős anyagi differenciálódása, és a meggazdagodott „vállalkozók” régi arisztokráciába történő betagozódása ${ }^{4}$, amely szintén hozzájárult a további befektetésekhez és a sziget-gazdaságok új gazdasági területek felé történő elmozdításához szükséges feltételek megteremtéséhez.

\section{A tókehal-üzlet}

A 16. század elején felfedezett új-fundlandi halászterületeken elég hamar megjelentek a szigetek halászai is, de e halban különösen gazdag területen történő halászat igazán meghatározó gazdasági tevékenységgé majd az 1600-as évek végétöl válik, különösen Jersey esetében, míg Guernsey gazdaságát sokkal inkább a kalózkodás és a csempészet határozta meg. 1763, Kanada brit uralom alá kerülése után a halászati területek megnyitásra kerültek, fokozva a gazdasági aktivitást. Maga a tőkehal-üzlet három fö tevékenységi kört jelentett:

- egyrészt a „tényleges” halászatot, melyet a szigetekről induló flották végeztek, majd a fogást tartósítva, a halat különféle piacokon értékesítették;

- a másik jellegzetes tevékenység a mások által kifogott és feldolgozott tökehal felvásárlása és további piacokra történő szállitása volt;

- harmadrészt pedig a halászterületeken élő népesség és a halászok ellátását szolgáló kereskedelmet jelentette.

Ez utóbbi típus egy jellegzetes fajtájának tekinthető az ún. truck system, melynek lényege, hogy a kereskedők a halászatban érintett területeken létesített lerakatokból elégítik ki a keresletet. A termékekért a halászok a fogással fizetnek, vagy rögtön, vagy a halászati szezon végén. A Csatorna-szigetek kereskedői, különösen a Jerseyi kereskedők, az 1800-as évek elejétől kezdve egyre inkább ebben a sajátos ellátókereskedelemben vettek részt a halászat helyett, komoly kereskedelmi monopóliumokat létrehozva. A tőkehal legfontosabb piacait Európa, Nyugat-India, DélAmerika, valamint a mediterrán kikötök jelentették. Sajátos, „háromszög” kereskedelem bontakozott így ki, ahol az első lépés a halászterületek ellátása, a második a tőkehal piacra juttatása, a harmadik pedig a hazaúton a tőkehal ellenértékért kapott termékeket, elsősorban dél- és közép-amerikai cukrot jelentette. Az ellátó kereskedelemben a Csatorna-szigetek helyi termékei számára is komoly felvevő-piacként jelentkezett az amerikai piac, másrészt együtt járt a hajóépítés nagymértékủ felfutásával, nem csak Jersey, hanem Guernsey esetében is. A kedvező pozíciók az 1860-as évektől kezdtek gyengülni (pl. 1854-töl egy kölcsönös kanadai-amerikai egyezmény értelmében amerikai hajók is használhatták a halászterületeket, változtak a vámszabályok az új-fundlandi területeken, melyek a profitot jelentősen csökkentették, a nyugat-indiai területeken protekcionista vámtételek jelentek meg a cukorkereskedelemben stb.). 1867-re a helyzet különösen kellemetlenné vált, a cukorüzlet a tőkehal-üzlettel együtt összeomlott, a szigeti hajók nem bírták a versenyt a gózhajókkal. Mivel a szigetek továbbra is fent kívánták tartani a korábbi prosperitást, 
Zádori Iván : A Csatorna-szigetek történetileg változó gazdasági-társadalmi kihívásai.

Tér és Társadalom 22. évf. 2008/2. 203-228. p.

sürgősen új lehetőségek után kellett nézni. A Jersey Chamber of Commerce jegyzőkönyveibỏl kiderül, hogy az érintettek a helyi mezőgazdaság, illetve a Csatornaszigetekre irányuló turizmus fejelsztését tekintették a lehetséges kivezető útnak, és 1886-tól már többet meg sem említik a Chamber of Commerce iratai a tókehalüzletet (Jamieson 1986).

\section{Hajóépités a Csatorna-szigeteken}

Valamilyen mértékủ hajóépítés szinte minden történeti korban létezett a Csatornaszigeteken, de a kereskedelmi aktivitáshoz és a kalózkodáshoz szükséges, nem jelentéktelen hajópark kialakítása az esetek többségében más forrásokból, elsősorban dél-angliai hajóépitö mühelyekböl történt, másrészt az elfogott ellenséges hajók használata is elég gyakori volt. A hajóípitésnek igazi lökést az amerikai forradalom és az amerikai gyarmatok elvesztése adott. Ezt megelözően a gyarmatok hajóépítési tevékenysége komoly jelentőséggel bírt, például 1775-ben a brit kereskedelmi flotta harmada amerikai építésủ volt. Az amerikai gyarmati hajóépítỏ kapacitáskiesés okozta ür jelentösen stimulálta a brit hajóépítőket, a tovagyürüző hatások a szigeteket is elérték, arról nem is beszélve, hogy a kalózkodás egyre inkább veszítve a jelentőségéböl, kevésbé müködött sikeresen (Jamieson 1986). A csempészet elleni 1805., illetve 1807. évi szabályok, a kalózkodás visszaszorulása, illetve Napóleon bukása utáni gazdasági visszaesés a szigeteket is jelentősen sújtotta és komoly munkaerő-piaci problémákat generált. Guernsey ekkor a dél-amerikai kereskedelmi lehetőségek, Jersey pedig a tőkehal-üzlet további fejlesztésében látta a kivezető utat. Mindkét aktivitáshoz hajók kellettek, amelyek egyre inkább a szigetek hajóépítő mühelyeiböl kerültek ki. A szigetek a hajóépítéshez számottevő faanyaggal nem rendelkeztek, tehát ezt behozatalból kellett fedezni, azonban nem az angol piacokról szerezték be a komoly vámokkal sújtott árut, hanem kihasználva, hogy a szigetek az angol vámterületen kívül helyezkedtek el, Európából, a Baltikumból és Franciaországból importáltak vámmentesen nyersanyagot. Ez a kedvező helyzet egészen 1845-ig állt fenn, amikor a brit faárukra kivetett vámokat jelentősen csökkentették. Ettỏl kezdve, bár nem kizárólagosan, Angliából származó faanyagot is felhasználtak a hajóépítéshez. További előnyt jelentett, hogy a munkabérek mindkét szigeten jóval alacsonyabbak voltak, mint az angol hajóépítỏ mühelyekben. A hajoépítés természetesen nem csak a saját igények kielégítését jelentette, hanem a külső kereslet kielégítését is. A hajóépitỏ mühelyek a kis jachtoktól egészen a nagy óceánjáró vitorlás hajókig bármit képesek voltak építeni, ugyanakkor gőzhajók építésében már egyik sziget sem rendelkezett komparatív előnyökkel.

A fahajoépítés viszonylag kevés felszerelést igényelt, nem kellett túlságosan nagy tőkebefektetés. A szükséges mesteremberek, vitorlakészítők, hajóácsok, kovácsok és kötélverők szerszámaikkal együtt helyben rendelkezésre álltak. Külön mühelyt sem igényeltek feltétlenül, hiszen a sima tengerparton is el lehetett kezdeni a munkálatokat (később tetőt állítottak föléjük). A munkaerő nem volt szervezett, mint 
Zádori Iván : A Csatorna-szigetek történetileg változó gazdasági-társadalmi kihívásai.

Tér és Társadalom 22. évf. 2008/2. 203-228. p.

TÉT XXII. évf. 2008 — 2

Kitekintö

213

Angliában, ezért a munkabérek szinte folyamatosan alacsonyak maradtak. A hajóépítésen kívül a már jóval több és speciálisabb felszerelést igénylö hajójavítás is megjelent, bár korántsem olyan súllyal, mint az építési tevékenység. Az 1850-es évektől a Csatorna-szigetek a brit trendeket és igényeket követve áttértek a gyorsabb járatú klipperek építésére, az alkalmazkodás a kihívásokhoz és változásokhoz folyamatos, és ekkor még sikeres volt. Persze ez a tevékenység sem volt versenytársak nélküli: a brit hajóépító mühelyeken kívül Kanada jelentette az egyik legfontosabb versenytársat. A vashajók megjelenésével és elterjedésével azonban a csatorna-szigeteki hajóépítésnek leáldozott, ismét ủj diverzifikációs lehetöségek után kellett nézni a szigetlakóknak.

\section{Mezögazdaság, helyi halászat}

Harvey, Quilley és Beynon Exploring the Tomato. Transformations of Nature, Society and Economy címü könyvében (2002) egy fejezetet kitevő, részletes beszámoló mutatja be a Guernsey-szigeti üvegházi paradicsomtermelés felfutását, majd hanyatlását. A történet nagyrészt termelés- és értékesítés-szervezésről szól, a hanyatlás okainak hátterében pedig az energiaárak robbanása, a külföldröl jövő erőteljes kínálat hatása, a modern, ám a kis családi cégek számára megfizethetetlen technológiák elöretörése és ezzel a hagyományos termelés ellehetetlenülése áll. Hasonló jellegü felfutási, illetve hanyatlási periódusok jellemzik a szigetek mezögazdasági folyamatait, mint a korábban már vázolt egyéb gazdasági tevékenységeket is, folyamatos az alkalmazkodási kényszer, a világgazdasági trendek és a változó igények függvényében. A szigetek mezőgazdaságát a 16. századig alapvetően a helyi piacok ellátása jellemezte, csak a többlet került exportra, ettől kezdve a hagyományos és a szigetlakók ellátását biztosító termelés mellett megjelentek az első „hullámok”. A lehetöségek azonban nem korlátlanok, a növekvő népesség egyre több mezőgazdasági müvelésre alkalmas területet foglalt el, és a váltások esetén az ủj termékekre való átállás általában csak más termékek rovására történhetett meg.

Az első ilyen felfutás a 15-16. századi kötőipar felvirágzásához köthető birkatenyésztés, az egyre inkább növekvő gyapjủigényt kezdetben szigeti forrásokból, majd idővel behozatalból fedezték, sokszor a többi mezőgazdasági tevékenység rovására. A 17. században a dohánytermesztés is felfutott, de a szigetek termelése az észak-amerikai új ültetvényeknek jelentős versenyt generált, ezért a Privy Council megtiltotta a termesztést (nemcsak a szigeteken, hanem Angliában is). A 17. századtól almatermesztés terjedt el, olyannyira, hogy az a gabona és egyéb termények rovására ment - 1673-ban pl. Jersey-n megtiltották új ültetvények telepítését, csak abban az esetben engedélyezte az állam, ha a régi almáskerteket telepítették újra (Coysh 1977). Az almabor több évszázadon keresztül jelentös exporttermék volt, Jersey-n például 1815-ben a megmúvelhetö területek negyede almáskert volt. 1855-ig a termelés fokozódása figyelhető meg, mely 1870 -re jelentósen viszszaesett, átadva a terepet a burgonyának. Az almatermelésnek különösen Jersey 
esetében volt kitüntetett szerepe, Guernsey-n nem annyira jelentős, itt az alma mellett körtét is termesztettek, majd az 1870-es évek magasságában egyre inkább áttértek az üvegházi termelésre, a zöldség-, valamint a szőlötermesztésre.

A kertészet és zöldségtermesztés hosszú múltra tekint vissza a szigeteken, melyhez kedvező feltételeket biztosít a szigetek viszonylag enyhe éghajlata. A legtöbb primőráru elöbb érik be, mint a kontinensen vagy Angliában, és a rendszeres hajójáratok megindulása után viszonylag könnyen lehet eljuttatni a célpiacokra. Az enyhe éghajlat ellenére nagyrészt fütött üvegházakban a paradicsom mellett egy sor további haszonnövénnyel, brokkolival, karfiollal, spárgával, salátával, eperrel, paprikával is kísérleteznek, valamint virágokat (frézia, írisz, krizantém) is termesztenek. A virághagyma és virágüzlet az 1860 -as évektől kapott lendületet, Guernsey-röl például 1933-ban már évi 5 ezer tonna virágot exportáltak, majd néhány évtized múlva a virághagyma-export is beindult, föleg az amerikai, kanadai, holland, angol és dél-amerikai piacokra. A piaci verseny azonban erős volt, egyrészt a szomszédos francia területeken is hasonló növényeket termesztenek, másrészt szinte ugyanezek a ,próbálkozások" figyelhetők meg több, az angol partokon elhelyezkedő sziget termelési struktúrájában is. Egy idő után a legtöbb haszonnövény esetén a termelés visszaszorult, nem versenyképes és veszített korábbi jelentöségéből annak ellenére, hogy a logisztika és marketing tevékenységek sziszematikus koordinálására több próbálkozás figyelhető meg.

A Csatorna-szigetek marhái, a ,guernsey-k" és a ,jersey-k" jól tejelö, igen magas zsírtartalmú tejet adó állatok. 960 körül Róbert normandiai herceg hozott szerzeteseket a szigetekre, akik egyházi tevékenységük és a sziget védelme mellett gazdálkodással is foglalkoztak. Az első tehenek valószínüsíthetően velük érkeztek a szigetekre (Breeds of... 2006). A Csatorna-szigetek elzártsága sok betegséggel szemben ellenálló fajokat eredményez, amihez természetesen az is kell, hogy az importot szabályozzák: a korlátozások Jersey esetében 1789-ben, Guernsey esetében 1819ben következtek be, amikor is hatóságilag megtiltották a francia állatbehozatalt. Az igazi export-felfutás az 1800-as évek második felében indult meg, noha korábban is lehet beszélni kivitelröl.

A Csatorna-szigeteken a helyi halászatnak is nagy jelentősége volt az évszázadok folyamán, amely egyrészt a helyi igények kielégítését szolgálta, másrészt pedig a keletkezett többlet folyamatosan exportálásra került, az új-fundlandi tőkehal-üzlet beindulása után azonban sokat veszített jelentőségéből. A későbbiekben az 1910-es évektöl újabb felfutás figyelhetö meg, majd hanyatlás a hetvenes évekig, utána újabb felfutás tapasztalható. Érdekes momentum Jersey esetében az osztrigahalászat: a sziget és Franciaország között nagy osztrigatelepeket találtak 1797-ben. A halászat azonban nem volt teljesen konfliktusmentes, a francia halászokkal folyamatosak voltak az összetüzések és feszültségek a halászati jogok gyakorlását tekintve. A korlátozások, szabályozások ellenére az osztrigatelepek teljesen kimerültek, és az 1870-es évekre az osztrigahalászatnak is leáldozott. 


\section{Turizmus}

A szigetek természeti szépségei, enyhe éghajlata, különleges értékei és érdekességei a kontinens és a szigetek között rendszeressé váló hajójáratok beindításával az idegenforgalom rohamos térhódítását eredményezték a 19. század közepétől. A Csatorna-szigeteken szinte minden kor „hagyott” valamit, a kőkori szentélyektől, dolmenektöl, menhírektöl kezdve a középkori templomokig, várkastélyokig, a különféle korokból származó katonai erődítményektől kezdve a hangulatos kikötökig, ódon világítótornyokig szinte minden megtalálható, jelentős kínálati elemeket biztosítva az idelátogató turistáknak. A 19. század folyamán, hála a fejlődést előtérbe helyezö kormányzóknak, a jelenlegi infrastruktúra jelentős része kiépitésre kerül, Guernsey-n például 1829-re $85 \mathrm{~km}$ első osztályú és $28 \mathrm{~km}$ másodosztályú út épült. $\mathrm{Az}$ építkezésekhez az alapanyagot helyben termelték ki, és a belső építkezéseken kívül fontos kiviteli kereskedelmi cikként jelent meg a kitermelt gránit. Az épitkezésekkel kezdődően megindult a városiasodás, nem utolsósorban azért, mert 1831-ben kolerajárvány tombolt, jelentős emberáldozatokkal, és nyilvánvalóvá vált, hogy a településeket mindenképpen hozzá kell igazítani a megnövekedett számú népesség igényeihez. További kedvezö feltételként jelent meg a hagyományos küldöterületek közelsége, valamint a „nyelvi problémák" hiánya is, meg kell azonban jegyezni, hogy hasonlóan a korábbi átállásokhoz, itt is csak más területek hanyatlása után indulhatott be az új iparág, természetesen a többi gazdasági tevékenység rovására. Bár mindkét szigeten növekedett a népesség, a rendelkezésre álló humán erőforrások köre továbbra is erösen korlátozott volt, másrészt már ebben a korban sem volt egyszerủ a szigeteken történő letelepedés, nagyarányú bevándorlás vagy vendégmunkás-beáramlás nem tapasztaló.

\section{A II. világháború}

A II. világháború megakasztotta a Csatorna-szigetek töretlen fejlődését: a német csapatok 1940 elején elfoglalták Normandiát. A szigetek lakóinak egy részét evakuálták Angliába. Az előzetes várakozások ellenére 1940. június végén a németek elfoglalták a szigeteket. A megszállás alatt 37 ezer német katona állomásozott a térségben. A németek hatalmas erődítési munkálatokat végeztek, bunkereket, ágyútornyokat, géppuskafészkeket és erődök tömegét építették fel, arra számítva, hogy a szövetségesek itt is támadni fognak. 1942-ben a szigeteken is megkezdődtek a deportálások, hozzávetőlegesen 2000 zsidó és nem zsidó származású brit angol állampolgárt hurcoltak koncentrációs táborokba. Alderney szigetén pedig három munktábort alakítottak ki, ahová megközelítően 800 ember került Európából.

A német megszállás alatt a szigetek irányítása többé-kevésbé saját hatáskörben maradt, német felügyelettel, amely az operatív irányítást tanácsoknak adta át (Controlling Committee, Guernsey; Superior Council, Jersey) különféle bizottságokat létrehozva, amelyek egy-egy terület irányításáért és koordinálásáért feleltek 
(Potato Board, Guernsey Farm Product Board stb.). A helyi gazdaság átalakítására és központositottabb irányítására már csak azért is szükség volt, mert a korábbi meghatározó angol kapcsolatok megszüntek, a keletkező ür a megmaradt francia kereskedelmi kapcsolatokból került kielégítésre, de nem csupán a maradék helyi lakosság, hanem az itt állomásozó német csapatok ellátását is meg kellett oldani. Egyes javak (olaj, vetỏmag stb.) hiánya már ekkor megmutatkozott. A két sziget eltérő adottságainak és a meglévő termelési struktúrájának köszönhetően a kvázi önellátás tekintetében Jerseynek sokkal kedvezőbb lehetőségei voltak, Guernsey-n a virágtermesztést felszámolva próbáltak további termöterületeket nyerni. Guernsey-n fokozta a problémákat az is, hogy a megszállók lóállományát is takarmányozniuk kellett, ami 437,4 hektár földterületet érintett, tovább csökkentve a mủvelhetô és a helyi lakosság ellátását szolgáló földterületeket. Jersey-n is hamar felváltotta a búza, az árpa és a zab a burgonyát. 1941-re Jersey képes volt a civil lakosságot elég liszttel és tejjel ellátni. Amit nem sikerült előállítani, Franciaországból pótolták egészen addig, amíg teljesen el nem szigetelődtek. A különféle eröfeszítéseket az is mutatja, hogy 1941-42-ben a német hatóságok engedélyt adtak arra, hogy az evakuálás következtében teljesen lakatlanná váló, csak a korábban említett három munkatábornak helyet adó Alderney szigetén egy kisebb csoport mezőgazdasági tevékenységet folytasson, ezzel is növelve a rendelkezésre álló javak mennyiségét. Hasonló történt Sark esetében is, ahol burgonya termesztésével próbálkozott a Guernsey Agricultural Department, bár 1944-tól a müvelés a háborús tevékenységek következtében megszünt. A várt szövetséges partraszállás azonban nem a Csatorna-szigetek térségében történt meg, Guernsey és Jersey szinte teljesen elszigetelödött, melynek eredményeképpen a megszállók és a szigetek lakossága, utánpótlás hiányában a háború végére majdnem éhen halt. 1944. december 27-én a Vega nevü vöröskeresztes hajó kötött ki Guernsey-n, megmentve az embereket az éhezéstől. A Csatorna-szigetek 1945. május 9-én szabadul felt, a megszállók csak ekkor adták meg magukat.

A háborús évek mindenképpen tanulságosnak tekinthetők, hiszen megmutatkozik (természetesen nem csupán sziget-specifikusan, hiszen hasonló folyamatok figyelhetők meg számtalan kontinentális ország tekintetében is), hogy mi történik akkor, ha egy adott, erősen importfüggő terület fenntarthatóságát, múködését biztosító külsö kereskedelmi kapcsolatok egyszer csak megszünnek.

\section{A paradicsom-termesztéstöl az adóparadicsomig}

A II. világháború után az élet a Csatorna-szigeteken hamar normalizálódott, az evakuált lakosság visszatért a szigetekre, újra beindultak a térség korábbi ellátását biztosító kereskedelmi kapcsolatok, a „hadigazdaság” helyett a korábbi sikeres exporttermékek elóállítása és a turizmus is. Az ötvenes évek közepéig, végéig a korábbi gazdasági tevékenységek és exporttermékek megfelelő szinvonalon biztosították a szigetek megélhetését, azonban egyre inkább nyilvánvalóvá vált, hogy a legtöbb korábbi exporttermék a fokozódó nemzetközi verseny miatt hosszabb távon 
kevésbé versenyképes. Az ötvenes évek közepének gazdasági-társadalmi mozgásfolyamatai új irányt szabtak a Csatorna-szigeteknek, és fokozatosan megindultak a pénzügyi központ-szerep felé vezető úton. A történet alapvetően az eddig „,megszokottak" szerint történik, a szigetek az anyaországhoz füződő sajátos viszonyrendszerből profitálnak, amelyhez természetesen mindkét partner szükséges, és mindkét fél számára hasznos.

Az ötvenes éveket megelőző időszakban a pénzügyi tevékenységek abszolút nem tekinthetők dominánsnak a Csatorna-szigetek gazdasági életében, ugyanakkor a sok esetben több évszázados törvények, valamint az Egyesült Királyság és a térség gazdasági-politikai viszonyrendszerét szabályozó rendelkezések jó néhány kedvező elemet biztosítanak az új diverzifikációs lehetőségnek. A kedvező feltételek Hampton (1998) alapján az alábbi pontokban foglalhatók össze:

- A brit kormány a hatvanas évektől kezdve, közvetve a Bank of Englandon keresztül, lehetővé teszi az europiacok lérehozását és a különféle offshore központok fejlödését - elsősorban az anyaországgal sajátos viszonyrendszerben lévő szigeteknek;

- A közvetlen, magánszemélyekre és üzleti vállalkozásokra vonatkozó adófizetési kötelezettség hagyományosan $20 \%$ mindkét sziget esetében (nem azért határozták így meg, hogy adóparadicsommá váljanak);

- A szigeteken nincs tőkenyereségadó, forgalmi adó és vagyonátruházási adó;

- Az itt alapított vállalatokra a helyi szabályozások és nem az egyesültkirályságbeli törvények vonatkoznak, ami kedvezỏ feltételeket kínál a befektetöknek;

- Ingatlan-ügyletek lehetősége: az akkori, 1961-ig érvényben lévő brit törvényi szabályozás értelmében a brit állampolgárok külföldi ingatlanjai nem adókötelesek, és a Csatorna-szigetek ebből a szempontból „külföldnek” számítanak;

- Biztonság és politikai stabilitás;

- Kellemes éghajlat;

- Könnyủ elérhetőség, megközelíthetőség;

- Londoni pénzügyi központ közelsége, ugyanaz az időzóna, angolul beszélö, viszonylag jól képzett munkaerő.

A magas helyi banki kamatok a kezdeti nagyfokú tőkebeáramlásban nem játszottak jelentős szerepet, érdekes, hogy egy „ösi”, 1771-es és 1962-ig érvényben lévő uzsoraellenes törvény a helyi kamatrátát 5\%-ban maximálta, amely a Csatornaszigeteken müködő egyesült-királysági klíringbankokra is vonatkozott. Ebböl következően, amikor az angol kamatráták a helyi kamatrátáknál magasabbak voltak, elméletileg tökekiáramlást kellett volna tapasztalni, de ez még akkor sem történt meg, amikor például 1957 szeptemberében a kamatláb az Egyesült Királyságban 7\% fölé kúszott. A gazdaság elmozdulása legkorábban Jersey esetében történik meg, majd némi, néhány éves fáziskéséssel követi Guernsey is.

Jersey-n 1955-ben még csak hat bankocska müködött, négy angol klíringbank, a Jersey Savings Bank és egy kis helyi bank. A hatvanas évektől kezdve azonban 
jelentős tőkebeáramlás indult meg, a bankok száma 1971-re elérte a 30-at, a bankbetétek pedig a 470 millió fontot. A korábban már említett ingatlan-boom pedig az 1961-es törvényi változásig 12 millió font beáramlását eredményezte a szigetre. 1969-ben Jersey esetében a GDP 45\%-a még a turizmus bevételeiből, de 15\% már a pénzügyi szektorból származott, egyre inkább offshore központtá vált, pénzügyi szolgáltatások széles körét biztosítva. Guernsey-n 1963-ban nyílt meg az első kereskedelmi bank, némi fáziskéséssel, de a hasonlóan stabil kormányzat, a kedvezö gazdasági, politikai környezet számtalan bank- és biztosítótársaságot, pénzügyi befektetöt vonzott a szigetre. Jersey és Guernsey sikere természetesen a harmadik hasonló jogi státuszú koronagyarmatot, a Man-szigetet sem hagyja érintetlenül. A hatvanas évek végén ott is megkezdödött az átállásra való felkészülés, ami ténylegesen „komolyabb” elökészületeket kívánt, mert amíg a Csatorna-szigetek esetében az adókulcsok hagyományosan alacsonyak voltak, addig a Man-sziget esetében szükség volt az adórendszer átalakítására (1961, 1979 és 1981), ami intenzívebb kormányzati beavatkozást igényelt. Ebben az esetben a Csatorna-szigeteknél jóval nagyobb területủ és alacsonyabb népességszámmal rendelkezö sziget pénzügyi központ szerep felé történő elmozdítása alapvetóen azért került elötérbe, hogy a gazdasági recesszió miatti elvándorlást és a hanyatló népességszámot lehetöség szerint megállítsák (Le Rendu 2004). Guernsey és a Man-sziget dolgát jelentősen megkönnyíti, hogy ott „lebeg” elöttük Jersey sikeres példája, ugyanakkor az alapvetően hasonló adottságokkal és kínálati elemekkel rendelkezö szigetek között egyre intenzívebb verseny, majd egyfajta „piacfelosztás” következik be: Jersey elsősorban a vezetö banki szereplőkre, a nemzetközi privát banki tevékenységekre és az alapkezelésre koncentrál, Guernsey esetében a biztositótársaságok és a kevésbé tőkerős bankok jelentik a fö piacot, a Man-szigeten pedig a privát banki mủveleteken kívül lehetőség van a hajóregisztrációs ügyletekre és a szabad légikikötő használatára is.

A pénzügyi szolgáltatások felfutásával a hagyományos gazdasági tevékenységek közül a Csatorna-szigeteken a mezögazdaság erőteljes hanyatlásnak indult, a turizmus viszont mindkét sziget esetében még hosszú ideig jelentős maradt, amely több szállal kapcsolódik a pénzügyi szektorhoz. A pénzügyi szektor fejlődésével párhuzamosan az információs technológiával összefüggö iparágak jelentős terjedése is megfigyelhető a szigeteken, különösen Guernsey esetében. A Csatorna-szigetek a nyolcvanas évekre komoly, nemzetközi jelentőségü offshore központokká váltak, ahol teljes körủ pénzügyi szolgáltatások igénybevételére és tevékenységek folytatására nyilik lehetőség. A szigetek a pénzügyi központ-jelleg és az Egyesült Királysághoz füződő sajátos viszonyrendszer további fenntartásában érdekeltek, ami nem csupán arról szól, hogy az itt befektetni szándékozókat kellőképpen „elbüvöljék”, hanem egyrészt komoly versenykihívás (egyéb pénzügyi központok, más, az Egyesült Királysággal föderalisztikus kapcsolatban álló szigetek, külső sziget-szereplök), illetve folyamatos egyeztetés az angol, amerikai és uniós szervekkel és megfelelés a nemzetközi egyezményeknek és elöírásoknak (Privy Council, Home Office, United States Federal Reserve, Commissions of the EU stb.). Bizonyos területeken azonban a gazdasági-politikai keretfeltételeken kívül a magasfokú autonómia ellenére is 
szükség van az Egyesült Királyság közremüködésére, amely ismételten jól szemlélteti a sajátos kölcsönös viszonyrendszer szükségességét.

A magas szintủ pénzügyi szolgáltatások nyújtásához szükséges megfelelö szakmai képzésre a szigeteken felsőoktatás hiányában nincs lehetőség, ugyanakkor az angol belügyminisztériummal kötött, évente megújitásra kerülő egyezmények értelmében és a szintén évente megállapitott felsőoktatási hozzájárulás fejében a szigetekről továbbtanulni szándékozó diákok számára biztosított az angol egyetemekhez való hozzáférés. Hasonló a helyzet az egészségügy területén is, ahol szintén kölcsönös megállapodások szabályozzák a brit állampolgárok szigeteken történö, illetve a szigeti lakosság egyesült-királysági ellátását. Ennek elsősorban azért van kiemelt jelentősége, mert a szigetek állandó, illetve tartózkodási engedéllyel rendelkező és a szigeteken tartózkodó lakosságának egy jelentős része brit állampolgár. További együttmüködést kíván a szigeteken müködö rendőrség, tüzoltóság, valamint az iskolák felügyelete és minőségbiztosítása, a vámhatóságok, bevándorlási hatóságok mủködtetése és a fizetőeszközök közötti átválthatóság fenntartása is. ${ }^{5}$

\section{Új kihivások}

A szigetek gazdaságtörténetének áttekintéséböl kitünik, hogy az elmúlt évszázadokban számtalan olyan alkalmazkodási „kényszerhelyzet” figyelhetö meg, ahol a hosszabb távú fenntarthatóság érdekében - bizonyos esetekben tudatosan, más szituációkban kevésbé strukturált módon - át kellett alakítani a korábbi gazdasági, társadalmi tevékenységeket. Ezen változásokat alapvetỏen a piaci folyamatok, (világ)gazdasági trendek és szükségletek generálták, alapvetően sikeres formákat létrehozva. Napjainkban sincs másként, azonban a korábbi kevésbé tervezett adaptációs tevékenységek helyére a hatvanas évektôl kezdve egyre inkább a szisztematikus tervezés lépett. A problémák és kritikus pontok egy részét különböző politikákkal, stratégiákkal és tervezéssel, az erőforrások és az Egyesült Királysággal fennálló sajátos viszonyrendszer menedzselésével próbálják meg kezelni, azonban több olyan terület is létezik, amelyre számottevő befolyással a Csatorna-szigetek nem bírnak, ilyen például a klímaváltozás vagy a tengerszint emelkedésének kérdése. A sziget-statégiákat és jelentéseket ${ }^{6}$ áttekintve a következő területek tekinthetők hangsúlyosnak:

- Gazdasági versenyképesség fenntartása;

- Népességnövekedés, népességszabályozás, demográfiai trendek;

- Foglalkoztatás, oktatás;

- Infrastruktúra fejlesztése, zsúfoltság csökkentése;

- Víz-, hulladék- és energiagazdálkodás;

- Környezetvédelem, külső környezeti változások;

- Életminőség.

A következőkben ezek a kiemelt területek kerülnek áttekintésre, szem előtt tartva, hogy az egyes dimenziók sok szállal kapcsolódnak egymáshoz, és az egyes területek között jelentős az átfedés. 


\section{Gazdasági versenyképesség fenntartása}

A Csatorna-szigetek gazdasági teljesítménye, amelyet napjainkban leginkább a pénzügyi szektor túlsúlya jellemez, nemzetközi viszonylatban és összehasonlításban is kifejezetten jónak mondható, az egy före jutó GDP 2005-ban Guernsey esetében 44600 dollár, Jersey-n pedig 57 ezer dollár volt (CIA Factbook 2007), a szintén 2005-ös GNI adatok alapján pedig mindkét sziget az elsö 4 között található. Az egyes szektorokat tekintve mindkét szigetnél egyértelmủ a pénzügyi szektor túlsúlya, a hagyományos iparágak, a mezőgazdaság és a turizmus viszont már sokat veszített korábbi jelentőségéből. Guernsey esetében a pénzügyi szektor bevételeinek növekedésén kívül az építőipar jelentős, illetve a web-alapú gazdaság és egyéb üzleti tevékenységek bevételeinek kisebb volumenü növekedése figyelhető meg, a hagyományos tevékenységek további lassú hanyatlásával. Jersey esetében a legtöbb hozzáadott érték a pénzügyi szektorban keletkezik, érdekes módon az építőipar teljesítménye a többi szektor teljesítményéhez képest itt is viszonylag magas.

A szigetek „államháztartása" mindkét esetben komoly egyensúlytalanságoktól mentes, és Guernsey és Jersey esetében is lényeges elemként jelenik meg a stratégiai céltartalékképzés az esetleges anomáliák és egyensúlytalanságok leküzdésére. A kiskereskedelmi árindex-változással mért infláció mindkét sziget esetében hosszú idő óta magasabb, mint az Egyesült Királyság esetében, de lényeges aránykülönbségek nincsenek, a szigeteken jelentkező infláció együtt mozog az Egyesült Királyság rátájával. További gazdasági mutatókat tekintve a szigeteket a foglalkoztatás magas aránya és egészen elhanyagolható szintủ munkanélküliségi ráta jellemzi.

A Csatorna-szigetek jelenlegi gazdasági helyzete azonban nem kihívásoktól mentes. Guernsey esetében például 2005 novemberében egy független szakértői csoport jött létre, hogy a sziget társasági adóval kapcsolatos politikáját, illetve megváltozásának a sziget gazdasági pozíciójára gyakorolt hatását megvizsgálja. A jelentés (Radcliffe-Roper 2006) készítésének alapvető célja, hogy feltérképezze a 0-10\% közötti adókulcsứ társasági adó bevezetésének a sziget gazdaságára gyakorolt hatásait. Korábban a szigeten nem alkalmazott társasági adó bezetésének kérdése azért került napirendre, mert az európai uniós, üzleti adóztatási magatartást szabályozó kódex (Code of Conduct on Business Taxation - Primaloro Group 1999) ajánlásai alapvetően kedvezőtlen kategóriába sorolják a szigetet (Jersey esetében is ugyanez a helyzet). A sziget vezetői az alkalmazkodást és a „nemzetközi játékszabályok” betartását mindenképpen szükségesnek tartják, noha az említett kódex, amelyet 1997 decemberében az ECOFIN (Council of Economics and Finance Ministers) tett közzé, nem uniós jogforrás, csupán a közösség politikai ajánlásait tartalmazza. 2002-tốl kezdődött meg az adózási gyakorlat felülvizsgálata, hogy a pénzügyi központként történő további versenyképesség megmaradjon. A jövő útja a $0 / 10$ rátával rendelkezỏ társasági adó, amely a helyi cégeknek 0, a Guernsey FSC (Financial Services Commission) által szabályozott társaságok esetében 10\%-os adóterhet jelentenek 2008-tól. Ez a becslések szerint jelentős kieséseket jelent a jövőben, ezért 
Zádori Iván : A Csatorna-szigetek történetileg változó gazdasági-társadalmi kihívásai.

Tér és Társadalom 22. évf. 2008/2. 203-228. p.

TÉT XXII. évf. 2008 『 2

Kitekintó

221

elemzések sora foglalkozik esetleges más adófajták bevezetésével, illetve terhek növelésével, mint például a forgalmi adó kérdésével, a társadalombiztosítási járulékok növelésével, illetve további adóterhek benzinre, dohány- és alkoholtermékekre való kivetésével (Guernsey... 2006). Az elemzők úgy látják, hogy a Csatornaszigeteknek, természetesen beleértve a hasonló cipőben járó Man-szigetet is, a változásokra mindenképpen szüksége van. Az EU irányelveknek való nem megfelelés a későbbiekben komoly piacveszteséggel és versenyképesség-romlással járhat. $\mathrm{Az}$ adózási rendszer módosulása nem feltétlenül vezet komoly piacvesztéshez, mert ha azok a feltételek, amelyek szintén jelentősen befolyásolják a gazdasági szereplők piaci döntéseit, továbbra is megmaradnak - mint az egyszerü, átlátható rendszer, megfelelỏen képzett munkaerö, személyzeti költségek, kedvező bérleti lehetőségek és díjak, jó szálítási kapcsolatok, elérhetőség, megközelíthetőség, jó üzleti hírnév, megbízhatóság, a stabil politikai környezet, a vonzó lehetőségeket biztosító jogi és szabályozási keretek -, a versenyképesség továbbra is fenntartható.

A web-alapú gazdaság új diverzifikációs lehetőségként jelenik meg a Csatornaszigetek esetén is, az új gazdasági irány térhódításához szükséges feltételek alapvetően adottak, és a jövőben a pénzügyi központ-jelleg esetleges hanyatlásával új lehetőségként jelenhet meg az adóparadicsomból az „e-paradicsom” felé történő elmozdulás. Az esetleges elmozduláshoz szükséges jelenlegi elönyök egyébként hasonló jellegüek a korábbi időszakok elönyeihez, és leginkább a szigetek sajátos ,in and out" helyzetét használják ki, csak éppen a termékek változnak, amit jól szemléltet a következő példa. Az Európai Unió adószabályai között létezö, alacsony értékü termékekre vonatkozó adókönnyítés (Low Value Consignment Relief - LVCR) értelmében a 18 fontnál alacsonyabb értékü, az Unión kívülről származó importtermékek mentesülnek a forgalmi adó alól (E-commerce firms... 2006). Az Európai Unión kívüli Csatorna-szigeteken keresztül történő termékértékesítés ezért jelentős kedvezményeket és versenyelőnyt generálhat, amennyiben a forgalmazott termékek jelentős része 18 fontnál kisebb értékü (pl. CD-ktől, DVD-ktől kezdve a különféle kiegészítőkön, alkatrészeken keresztül a golffelszerelésekig stb.). E kereskedelem jelentős része interneten keresztül történő e-kereskedelem - tipikus példája az elsösorban CD-ket és DVD-ket forgalmazó Play.com Jersey-n. A szigetek Egyesült Királyságtól, illetve a kontinenstől való távolsága a kifejezetten jó elérhetőségi és megközelíthetőségi feltételek miatt komoly szállítási költségeket sem jelent. Az üzlet teljesen legális, a fennálló kereteken belül, és az Európai Unió 'tudomásával' zajlik, és nem is várható a szabályozás megváltoztatása a közeljövőben.

\section{Népességnövekedés, népességszabályozás, demográfiai trendek}

A Csatorna-szigetek jelenlegi népességnövekedése nem tekinthető számottevőnek, Guernsey esetében például 1991 és 2001 között mindössze 13 fö volt a nettó bevándorlási többlet: 1991 és 1996 között 634 fös csökkenés, majd 2001-ig 647 fös növekedés mutatkozott, eredményezve a 13 fös növekedést. A helyzet Jersey eseté- 
ben is hasonló, 2000 és 2002 között 190 fö többlet, 2003-2004 között 300 fös csökkenés, 2005-ben pedig 270 fös növekedés mutatkozott. Mindkét sziget esetén a bevándorlók számát és a népesség növekedését a lakhatási engedélyek kiadásának korlátozottsága tartja nagyjából egyensúlyban. A lakhatási engedélyeket általában határozott időre adják a hatóságok. Léteznek ún. compassionate engedélyek olyan személyek számára, akik valamilyen oknál vagy tevékenységnél fogva kötődnek a szigetekhez, illetve külföldi családtagok számára a helyi lakosok is kiválthatnak rövid távú engedélyeket. Ugyancsak rövid távú engedélyeket adnak ki a szigeteken keresett munkaerő számára, de csupán foglalkoztatottságuk idejéig. Jersey esetében egyébként az elmúlt néhány évtizedben viszonylag nagyarányú bevándolás történt. Jelenleg a sziget lakosságának csak 52\%-a Jersey-i születésü, 36\%-a az Egyesült Királyságból, a fennmaradó rész nagyrészt Portugáliából és Madeira szigetéről (7\%) származik, illetve jóval kisebb arányú európai ( $3 \%$ ) és egyéb (3\%) bevándorlókból áll.

Bár a szigetek populációja jelenleg nem mutat számottevő növekedést, a lakosság számának gyarapodásából adódó kérdések lényegesnek tekinthetők, elsősorban a lakásproblémák miatt. Guernsey összterületének ezidáig mintegy $15 \%$-a került beépítésre. A terület beépítettségi foka a 2004-es évben 0,2\%-kal nött. Ebbe a számba a történelmi emlékektől és romoktól kezdve az üvegházakon keresztül a repülötérig minden ember által létrehozott építményt és utat beleszámoltak. Annak ellenére, hogy Guernsey $85 \%$-a hivatalosan nem számít beépítettnek, a helyiek ennek a területnek a nagy részét is beépítettnek tekintik, tekintettel arra, hogy túlnyomórészt magánkertek és közparkok teszik ki az említett $85 \%$-ot. Jersey-n a beépítettség 1997-ben meghaladta a 20\%-ot. Egyre növekvő igény mutatkozik új lakóházak építésére. Mivel a már beépített területek telítettek, az új házak felépítésére csupán a be nem épített zöldterületeken, mezőgazdasági területeken nyílik lehetőség. Mindenképpen szükség van tehát a kormányzat által kontrollált lakásprogramokra, amelyek biztosítják a növekvő népesség számára a megfelelő lakhatási körülményeket. Guernsey esetében ez a statisztikák szerint minimálisan évi 180, maximálisan évi 300 lakás építését jelenti. A hatékony szabályozásnak köszönhetően 2006-ban az új épületek 99,5\%-a barnamezős beruházásként épült fel. A demográfiai trendek alapvetően a népesség elöregedésével összefüggỏ folyamatok miatt tekinthetők kedvezőtlennek, amely a szociális ellátórendszerek fenntarthatósága, valamint a gazdaság emberi erőforrás szükséglete miatt tekinthetö fontos kihívásnak.

\section{Foglalkoztatás, oktatảs}

A lakásproblémán túl lényegesek a foglalkoztatással összefüggő kérdések is. A jelenlegi népességnek a prosperáló gazdaság mellett nincsenek ilyen jellegủ problémái, de a populáció további növekedése ezt a szituációt is jelentős mértékben megváltoztathatja, másrészt folyamatosan szükség van a munkaerő és az emberi erőforrás fejlesztésére, oktatási szintjének növelésére és a gazdasági, technikai kihívásoknak történő megfeleltetésére. Guernsey-n a 2001-es népszámlálás adatai alapján 
Zádori Iván : A Csatorna-szigetek történetileg változó gazdasági-társadalmi kihívásai.

Tér és Társadalom 22. évf. 2008/2. 203-228. p.

TÉT XXII. évf. 2008 『 2

Kitekintö

223

32293 szigetlakó ált alkalmazásban, ami a sziget népességének 54\%-a. A munkanélküliség alacsony, az összes munkanélküli száma 338 fö körül mozog, de ez a szám tartalmazza az önkéntes munkanélkülieket, a munkanélküli segélyben nem részesülöket, valmint a betegség miatt tartósan munkaképteleneket is. Munkanélküli segélyben körülbelül 100 ember részesül, ami a foglalkoztatottak 0,3\%-a. Jersey esetében 53560 fö, a népesség megközelítően $60 \%$-a állt 2006 júniusában alkalmazásban. Jersey-n nincs munkanélküli segély, de regisztrálják a munkanélkülieket. A 2004-es 760 fös „csúcs” után a munkanélküliek száma az elmúlt években 400 fö körül stabilizálódott, a munkanélküliségi ráta pedig 2,1 és 2,3\% között mozgott.

Mindkét sziget esetében a pénzügyi és jogi területek, a kis- és nagykereskedelem, valamint a közszféra jelentkezik fő foglalkoztatóként. Jersey esetében az idegenforgalmi szektor, Guernsey esetében az információs és egyéb szolgáltatások mutatnak nagyobb arányú foglalkoztatást. A szektoronkénti fogalkoztatás 10 éves periódust tekintve (1996-2006) szintén tanulságos elmozdulásokat mutat, amelyböl jól nyomon követhetök a prioritás-változások: Guernsey esetében a legnagyobb növekedés a közszféránál figyelhetö meg, csak ezt követi a pénzügyi szektor, illetve az információs és egyéb szolgáltatások kedvezőbb helyzete figyelhető meg, mint Jersey esetében, ugyanakkor az oktatási és egészségügyi szektor által foglalkoztatottak száma Jersey esetében nagyobb. A hagyományos iparágak, a turizmus, az ipari termelés, a mezőgazdaság hanyatlása ugyanakkor többé-kevésbé hasonló módon mindkét sziget esetẻn megfigyelhető.

A Csatorna-szigeteken felsőoktatási intézmény nem müködik, azonban az alapfokú, a középfokú és a posztszekunder képzés, a felnöttoktatás, valamint az információs társadalom kibontakozásával a távoktatás egyes formái is kiválóan müködnek. Az angliai és más országbeli egyetemeken való továbbtanulást egyébként mindkét sziget esetében az állam is támogatja. Nyilvánvaló, hogy a magas szintủ pénzügyi szolgáltatások biztosításához folyamatosan szükség van megfelelö felsöfokú szakmai végzettséggel és versenyképes tudással rendelkező munkavállalókra. A felnőttoktatás - mivel gyakorlatilag nincs munkanélküliség és a klasszikus munkaeröpiaci zavarok és egyensúlytalanságok sem jellemzők a szigeten-, szinte kizárólag a már korábban megszerzett tudás felfrissítésére és fejlesztésére, a hagyományôrzésre, a tétlenség elkerülésére, a közösség összetartására és nem utolsósorban a technikai, gazdasági, kulturális és a társadalmi fejlődés eredményeinek megismerésére és elsajátítására irányul. Érdemes végül megjegyezni, hogy a szigeteken rendelkezésre álló emberi erőforrás kereslet és kínálat között nem tökéletes az összhang, ami szinte minden szektorban a különösebb képzettséget nem igénylö mezőgazdasági idénymunkástól a magasan képzett fehérgalléros munkavállalókig időről időre, általában határozott idejü munkavállalási engedélyekkel, külső munkaerő bevonását teszi szükségessé. 


\section{Infrastruktúra fejlesztése, zsúfoltság csökkentése}

A megfelelő szintü életminőség fenntartásához mindenképpen szükség van az infrastruktúra folyamatos fejlesztésére és a zsúfoltság csökkentésére is. Mindkét szigeten a lakosság számához képest a gépjármü-állomány nagy, ráadásul nem a hatalmas autóforgalomra készült keskeny utak hálózzák be a szigeteket, további problémákat okozva. A gondok kiküszöbölhetők a tömegközlekedés fejlesztésével és a gépkocsi-használat visszaszorításával. Az építőipar „virágzik” a szigeteken, melynek jelentös része az elavult és kisebb forgalomra és lakosságszámra méretezett infrastruktúra átalakítására, modernizálására irányul, ugyanakkor a rendelkezésre álló területek szükössége miatt szisztematikus és átgondolt tervezési munkát igényel.

Guernsey esetében a statisztikák szerint közel 40 ezer gépkocsi közlekedik, ami elég magas számnak tekinthető a lakosság számához képest. A sziget gépjármüforgalma az utóbbi években számottevően nem változott. Ez csúcsidöben 3708 és 4335 közötti gépjármüvet jelent az utakon, ami a sziget méretét tekintve, meglehetősen nagy számnak számít. Egyedül a busz, mint tömegközlekedési eszköz vált népszerübbé az elmúlt években. A buszon utazók számának megnövekedése a viteldijjak csökkenésének és a szolgáltatás minőségében végbement pozitív változásnak köszönhetö, melynek elérése és a buszközlekedés népszerüsítése fontos kormányzati stratégiai elemként figyelhető meg. A 2001-es népszámlálás időpontjában Jersey-n az egy háztartásra jutó átlagos gépjármüszám 1,48 volt, amely még a Guernsey-i adatokat is túlszárnyalja. Az elmúlt évek adatai némi csökkenést mutatnak (2005: 1,42), ugyanakkor a gépkocsik száma évröl évre folyamatos növekedést mutat, a szigeten 2006 decemberében 104534 gépjármủ közlekedett. A háztartások közel hatodának tulajdonában ugyakkor semmiféle gépjármủ nem volt. A zsúfoltság csökkentése Jersey szigetén is napirenden van, alapvetően Guernsey esetében vázolt elmozdulási lehetőségek alkalmazásával.

\section{Viz-, hulladék- és energiagazdálkodás}

A szigeteken korlátozott mennyiségben rendelkezésre álló vízkészletek, a háztartási és ipari hulladék lerakására alkalmas „felesleges” területek hiánya, valamint a nagyfokú energiafüggőség komoly fenntarthatósági kérdéseket vet fel és mindenképpen hatékony gazdálkodást kíván. A vízgazdálkodás mindkét sziget esetében már a múlt század huszas éveitől kezdődően megjelenik, a növekvő népesség, a mezögazdasági termelés és a turisták igényeinek kielégítése miatt kezdödik meg az átgondoltabb gazdálkodás. A három terület közül jelen pillanatban a vízgazdálkodás tekinthető a legkevésbé kritikusnak, a megfelelö mennyiségủ csapadék, valamint a természetes (Jersey) és mesterséges (Jersey, Guernsey) vízforrások és tározók a felmerülő igények kielégítésére alkalmasak. Ugyanakkor a természetes felszíni vizekben szegényes Guernsey esetében, ahol jelenleg három víztározó áll rendelkezésre, a stratégiai tervekben megjelenik egy, a tengervízböl ivóvizet elỏálító erőmü építésének terve is. Jelenleg a megépítésre még nem került sor, de kész tervek, forgatókönyvek és 
építési engedélyek léteznek arra vonatkozóan, hogy abban az esetben, ha szükség lenne rá, 12 hónapon belül fel lehessen építeni, és üzembe lehessen helyezni.

A kereskedelmi és ipari hulladék mennyisége mindkét sziget esetében csökkenő tendenciát mutat az elmúlt években, elsősorban az említett szektorokban végbemenő fokozott szelektív hulladékgyüijtési gyakorlat terjedése erdményeként. A háztartási hulladék-mennyiség azonban Guernsey és Jersey esetében is a kedvező újrahasznositási trendek miatt évröl évre növekvő mennyiséget jelent. Az összegyüjtött és újrahasznositásra alkalmas hulladékmennyiségnek a megfelelö technológia és kapacitások korlátozott volta miatt csak egy része kerül a szigeteken feldolgozásra, a nagyobb részét elsősorban francia feldolgozó ïzemekbe szállitják. A korábban vázolt trendeknek megfelelóen Guernsey szigetén a kereskedelmi és az ipari hulladék termelése csökkent 2006-ban, mig az egy före jutó háztartási hulladék 7\%-kal emelkedett a 2005-ös értékhez képest. 1999 óta 27\%-os emelkedés figyelhető meg a háztartási hulladék mennyiségében. A háztartási hulladék mennyiségéből az egy före jutó értékeket tekintve $102 \mathrm{~kg}$ újrahasznosított és $284 \mathrm{~kg}$ nem újrahasznosított háztartási hulladékot jelent, ami mintegy $26 \%$-os újrahasznosítási rátát mutat, amely 1999 óta 10\%-os növekedést mutat. Jersey esetében az újrahasznosítási ráta $28 \%$ volt 2006-ban. Bár az újrahasznositási ráták mindkét sziget esetében kifejezetten jónak mondhatók, a jövőben a hagyományos lerakási lehetőségek korlátozottsága miatt mindenképpen indokolt a recycling további fokozása.

Energiaforrások tekintetében a Csatorna-szigetek nagyrészt külső erőforrásokra utaltak. Az elsödleges energiaforrások jelentös része import, melynek egy részét elektromos áram előállítására fordították a helyi, nagyrészt olajtüzelésú erömúvekben. Az utóbbi években azonban az elsődleges olajimport mindkét sziget esetében csökkent, mert napjainkra Guernsey-t és Jersey-t is Franciaországgal elektromos kábel köti össze, így az elektromos áram importja jelentös mértékben megugrott, ugyanakkor a korábban fütésre és energiatermelésre használt olajimport visszaesett, illetve nem növekedett számottevően (ez egyébként a környezetvédelemnél kerül majd ismét elö, hiszen ezek a változások komoly hatással vannak a szigetek káros szennyezőanyag-kibocsátására is). A háztartások energiaszükséglete ugyanakkor évek óta fokozatos növekedést mutat. A trendeket jól mutatja, hogy például Guernsey esetében a 2004-es évben 3\%-os elektromos áram felhasználás növekedés tapasztalható a 2003-as értékhez képest, párhuzamosan a felhasználók 4\%-os emelkedésével. Az utóbbi 10 évben az energia felhasználás összességében 34\%-kal emelkedett. 2000 óta a háztartási import olaj felhasználása 2004-ig csökkent, majd ismét lassan emelkedik, párhuzamosan a közlekedésben felhasznált olajszármazékok viszonylag konstans mennyiségével. Jersey az elsödleges energiaforrások 99\%-át, az elektromos áram 98\%-át importálja. Az elektromos áram felhasználása az elmúlt 14 évben évi átlagosan 2,2\%-os növekedést mutat. A sziget energiafogyasztásának $65 \%$-át olajszármazékok, 28\%-át az importált elektromos áram, 6\%-át földgáz, és csupán 1\%-át szén és egyéb alternatív energiaforrások jelentik (Jersey inFigures 2006).

Az olajfüggőség mérséklődése a szigetek energiafüggőségét számottevően nem befolyásolta, hiszen gyakorlatilag csak a különféle típusú függőségek közötti átren- 
deződésnek lehetünk a tanúi. A jövőben tehát mindenképpen foglalkozni kell a kérdéssel, melynek egy lehetséges megoldása az árapály-erőmüvek építése, amelyhez a világon az egyik legnagyobb apály-dagály különbség kedvezö lehetőséget biztosít. Hogy nem csupán elméleti elképzelésekről van szó, jól mutatja, hogy Guernsey szigetén a kizárólagos imporfüggöség enyhítésére árapály-erőmủ megépítését tervezik, amely alkalmas lehet a helyi szükségletek jelentős részének kielégítésére.

\section{Környezetvédelem, külsö környezeti változások}

A Csatorna-szigetek természetes ökoszisztémáinak jelentős részét a korábbi történeti korok gazdasági-társadalmi aktivitásai nagyrészt eltüntették, ugyakkor a természetes és épített környezet közötti összhangot, a meglévö biodiverzitást, a különféle szárazföldi és tengeri madarak költő és telelö helyeit stb. mindkét sziget esetében megpróbálják fenntartani, ami nem csupán a szárazföldi, hanem a tengeri ökoszisztémák megörzésére is irányul. E tevékenységek jelentős részének megőrzését, valamint esetleges bővítését azonban csak az ember által „müködtetett” területek rovására lehet megtenni. A környezetterhelés terén a szigetek viszonylag jól állnak, a különféle szennyezőanyag-kibocsátási értékek elmaradnak a WHO által előirt maximális értékektöl. A környezettel kapcsolatos kérdések egy részét hatékony gazdálkodással, szabályrendszerekkel és korlátozásokkal lehet menedzselni, ugyanakkor a külső környezeti változásokra számottevő hatással nem bírnak, ezekben az esetekben leginkább a nemkívánatos változásokra való felkészülés és alkalmazkodási képesség fokozása lehet a követendö stratégia. A klímaváltozás hatására a levegő átlaghőmérséklete 1947 és 2006 között Guernsey szigetén például $1{ }^{\circ} \mathrm{C}$-kal nőtt (éves szinten $0,01{ }^{\circ} \mathrm{C}$-os növekedést jelent), a part menti vizek hőmérséklete mintegy $1,7{ }^{\circ} \mathrm{C}$-kal emelkedett, míg a növények virágzása közel egy hónappal korábbra tolódott. A klímaváltozás a szigeteken jelenleg leginkább a mezögazdaságban dolgozókat érinti kedvezötlenül: különösen a vágottvirág-termesztéssel és nemesítéssel foglalkozóknak kell a megváltozott körülményekhez alkalmazkodniuk. $\mathrm{Az}$ esetleges nagyobb tengerszint-emelkedés is komoly veszélyforrásként jelentkezik, mivel a lakosság egy része viszonylag alacsonyan fekvő területeken él.

Bár a külvilág sok esetben aggasztó környezeti trendjeire a Csatorna-szigeteknek komoly ráhatása nincsen, mindkét sziget esetében jellemzö különféle tengerentúli projektek támogatása és segélyek nyújtása. Jersey esetében 2006-ban a GNI 0,18\%-át fordították tengerentúli segélyekre és támogatásokra, 5,67 millió font értékben, Guernsey-n pedig a GNP 0,11\%-át, 1,75 millió font értékben. A számok, bár jelentôs mértékben elmaradnak az ENSZ által elöirányzott $0,7 \%$-os aránytól, mégis figyelemreméltóak, különösen akkor, ha figyelembe vesszük, hogy például 2005-ben csupán öt ország, Dánia $(0,81 \%)$, Hollandia $(0,82 \%)$, Luxemburg $(0,87 \%)$, Svédország $(0,92 \%)$ és Norvégia $(0,93 \%)$ lépte túl a $0,7 \%$-os küszöbértéket (Jersey in Figures 2006). 
Zádori Iván : A Csatorna-szigetek történetileg változó gazdasági-társadalmi kihívásai.

Tér és Társadalom 22. évf. 2008/2. 203-228. p.

TÉT XXII. évf. 2008 ॥ 2

Kitekintö

227

\section{Életminôség}

Az egy fơre jutó GDP Guernsey esetében 44 600, Jersey esetében pedig 57 ezer dollár volt 2005 -ben, a születéskor várható átlagos élettartam mindkét sziget esetében eléri, illetve meghaladja a 80 évet. (Férfiak esetén a várható élettartam ennél valamivel alacsonyabb, a nök esetében pedig közel 84 évet jelent!) A szigetek népességének egészségügyi, pszichikai állapota is kifejezetten jónak mondható. A bünözés sem igazán számottevő, bár az elmúlt években emelkedỏ tendenciát mutat mindkét sziget esetében. A komoly munkaerő-piaci zavarok hiánya és a jelenlegi gazdasági prosperitás és trendek mellett a Csatorna-szigeteken ténylegesen is lehetóség nyílik a viszonylag kiegyensúlyozott, komoly megrázkódtatásoktól mentes, biztonságos és élhetó életre.

\section{Összegzés}

A Csatorna-szigetek napjainkig tartó gazdaságtörténete folyatatos kihívások és alapvetően sikeres adaptációk sorozata. A szigetek vonzó geostratégiai pozíciója és az 1204 óta fennálló sajátos autonómiája kedvezett a sok esetben szintén sajátos kereskedelmi tevékenységek kibontakozásának. E kapcsolatrendszerben azonban a szigetek nem alárendelt szerepkörben, hanem kvázi egyenrangủ félként próbálták kihozni az adott gazdasági-politikai szituációból a lehető legjobbat, ami hosszú távon vizsgálva a két kormányzóságot, összességében sikeresnek bizonyult. E folyamatok kủlönösen a 16. századtól indulnak be látványosan, amikor a növekvő népesség ellátásából fakadó problémák és az adott kor gazdasági szükségleteinek megfeleltethetö, rendelkezésre álló erőforrások kimerülése miatt egyre nagyobb diverzifikációs kényszer volt tapasztalható. A változó külső gazdasági kihívások és a piaci verseny időröl időre újabb és újabb gazdasági tevékenységeket generált a szigeteken, biztosítva a vizsgált sziget-gazdaságok jólétét és gazdasági, társadalmi fenntarthatóságát, melyet az Egyesült Királysággal fennálló sajátos viszonyrendszer fenntartásával, de ugyanakkor számottevő külső segítség nélkül sikerült elérni. A II. világháború évei ugyanakkor rávilágítanak e rendszer sérülékenységére: a kereskedelmi kapcsolatok és a korlátozott importlehetőségek hiányában a korábbi népességszám és életminőség nem tartható fenn. A Csatorna-szigeteken a II. világháborút követó néhány évtizedben hatalmas gazdasági felfutás tapasztalható, amely a korábbi, elsősorban mezógazdasági és idegenforgalmi tevékenységek által dominált gazdaság átalakulását vonja maga után. A sikeres váltás elsősorban az Egyesült Királysággal évszázadok óta fennálló sajátos gazdasági-politikai viszonyrendszer hatékony ,menedzselésének” köszönhető, amely időről időre új kihívások elé állítja a szigeteket, a válaszok azonban összességében sikeresnek tekinthetök. A Csatornaszigetek a sziget-gazdságokat leíró modellvariációk (Zádori 2007) közül a PROFIT-modellbe illeszthetök be, bizonyos SITE-elemekkel, ahol a szigetek nem paszszív részesei, hanem aktív szereplői a gazdasági, politikai folyamatok menedzselésének, megpróbálva minél több előnyt kihozni a jelenlegi szituációból annak érde- 
kében, hogy továbbra is biztosítani lehessen a jelenlegi magas életminőséget, a gazdasági prosperitást és a biztonságos környezeti feltételeket a szigetlakók számára.

\section{Jegyzetek}

${ }^{1}$ Az Eurostat által a sziget meghatározásához alkalmazott öt ismérv a következö: a sziget területe legalább $1 \mathrm{~km}^{2}$ legyen, a sziget és a szárazföld közötti távolság legalább $1 \mathrm{~km}$, az állandó lakosok száma legalább 50 fö, a sziget és a szárazföld között nem lehet állandó kapcsolat, valamint az érintett szigeten nem található uniós ország fóvárosa.

2 Protocol 3, the United Kingdom's Act of Accession to the European Community in 1972.

3 III. Edward 1341-ben eltörölte a szigeteket sújtó vámokat.

${ }^{4}$ Victor Hugo a Magyar Elektronikus Könyvtárban is olvasható, „A tenger munkásai” címü regényében szemléletes képet fest Guernsey ezen periódusáról. (http://mek.oszk.hu/02600/02637/html)

${ }^{5}$ Mindkét sziget saját pénzzel (Guernsey font, Jersey font) rendelkezik, amely csak a szigeteken használható, de az angol fontot, ami egy az egyben átváltható a helyi fizetóeszközökre, elfogadják.

${ }^{6}$ Guernsey hivatalos honlapján elérhetők az egyes évek stratégiai tervei, 2002-tól 2006-ig, ill. az ezt megelözó időszak néhány jelentése is megtalálható az Interneten: http://www.gov.gg/ccm/navigation/ govermment/online-reports/. Hasonlóan Jersey hivatalos honlapján (http://www.gov.je) is olvashatók az egyes dokumentumok-

\section{Irodalom}

Analysis of the island regions and outermost regions of the EU. (2003) Part I. The island regions and territories. http:/www.ec.europa.eu/regional_policy/sources/docgener/studies/pdf/ilesrup/islands_partl_summary_en.pdf.

Beynon, H.-Harvey, M.-Quilley, S. (2002) Exploring the Tomato. Transformations of Nature, Society and Economy. Edward Elgar Pub.

Breeds of Livestock - Guernsey Cattle. (2006) http://www.ansi.okstate.edu/breeds/cattle/guernsey/ Letöltve: $2006,07.18$.

CLA Factbook. (2007) https:/www.cia.gov/library/publications/the-world-factbook/ Letöltve: 2007. 09. 27.

Coysh, V. (ed.) (1977) The Channel Islands. A New Study. David \& Charles, North Pomfret, Vermont.

E-commerce firms head for tax haven Channel Islands. (2006) - OUT-LAW News. 10. 26. http://www.out-law.com/page-7425. Letöltve: 2007. 04. 12.

Everard, J.A.-Holt, J.C. (2004) Jersey 1204: The forging of an island community. Thames \& Hudson, London.

Guernsey Domestic Corporate Taxation. (2006) http://www.lowtax.net/lowtax/html/jgydctx.html, Letöltve: $2007.08,11$.

Hampton, M.P. (1998) Mapping the Minefield: Theories of Island Offshore Finance Centres with Reference to Jersey. - Bowe, M.-Briguglio, I.--Dean, J.W. (eds.) Banking and Finance in Islands and Small States. Island Studies Series, Printer, London.

Jamieson, A.G. (ed.) (1986) A People of the Sea. The Maritime History of the Channel Islands. Methuen, New York.

Jersey in Figures. (2006) http://www, gov.je/Statistics/Statistical+Publications/Letöltve: 2007. 07.14.

Johnston, P. (1994) A Short History of Guernsey. 4th Editon. Guersey Press Co.

Le Rendu, L. (2004) Jersey: Independent Dependency? The Survival Strategies of a Microstate. ELSP, Bradford on Avon.

Moore, D.W. (2005) The Other British Isles. A History of Shetland, Orkney, the Hebrides, Isle of Man, Anglesey, Scilly, Isle of Wight and the Channel Islands. McFarland \& Company Inc., North Carolina.

Off The Coast of Europe. (2002) Study undertaken by Eurisles on the initiative of the Islands Commission of CPMR. http:/www.eurisles.com/strategie/Sommaire_EN.htm. Letöltve: 2006. 12. 12.

Primaloro Group (1999) Code of Conduct on Business Taxation.

Radcliffe, R.-Roper, J.J. (2006) The economic case for a $0 \% / 10 \%$ corporate tax rate structure in Guernsey. The economic impact of Guernsey's Tax Strategy. Paper One. http://www.gov.gg/ccm/general/online-reports/2006-reports/ Letöltve: 2006.08.11.

Zádori I. (2007) Sziget-gazdaságok, sziget-modellek. - Tudásmenedzsment. 2. 67-78. o. 